\title{
Changes in Soil pH and Exchangeable Acidity of Selected Parent Materials as Influenced by Amendments in South East of Nigeria
}

\author{
Mabel Ifeoma Onwuka*, Uzochukwu Victor Ozurumba, Ogadimma Simonpeter Nkwocha \\ Department of Soil Science and Meteorology, Michael Okpara University of Agriculture Umudike, \\ Umuahia, Nigeria \\ Email: "ifyonwuka2000@yahoo.com
}

Received 6 September 2015; accepted 9 May 2016; published 12 May 2016

Copyright (C) 2016 by authors and Scientific Research Publishing Inc.

This work is licensed under the Creative Commons Attribution International License (CC BY). http://creativecommons.org/licenses/by/4.0/

(c) () Open Access

\section{Abstract}

Soil chemical degradation caused by acidity is a serious constraint to food production in most parts of the Tropics. It was in the bid to proffer solution to this that the present study was conceived. Anincubation study was conducted at the laboratory of Soil Science and Meteorology Department of Michael Okpara University of Agriculture Umudike. The aim was to ascertain the effect of amendments namely: Control (no amendment), Biochar, Ash, Lime, Biochar + Poultry Manure, Ash + Poultry Manure and Lime + Poultry Manure, on soil pH and exchangeable acidity of Sandstone, Shale and Alluvium. The rate of application was $1.43 \mathrm{~g}$ for the sole amendments and $0.72 \mathrm{~g}$ each for the combined amendments to give an equivalent of $2 \mathrm{t} / \mathrm{ha}$. They were applied to $100 \mathrm{~g}$ of the soil and replicated three times in a Completely Randomized Design. The incubation study lasted for eighty-four days, the $\mathrm{pH}$ and exchangeable acidity were determined at fourteen days intervals. The result obtained revealed that all the treatments increased the soil $\mathrm{pH}$ and decreased the exchangeable acidity over the control. In all parent materials, applied Lime and Lime + Pm significantly $(p<0.05)$ gave the highest $\mathrm{pH}$ of $6.6,6.9$ and 7.2 for Shale, Sandstone and Alluvium respectively on the $28^{\text {th }}$ day of incubation which, was the time, the maximum $\mathrm{pH}$ value was attained. Biochar and Biochar $+\mathrm{Pm}$ were considered the appropriate amendments because the $\mathrm{pH}$ values they gave were towards neutral, unlike that of Lime and Lime + Pm that were towards alkaline. It is recommended that field trial of this work is conducted.

\section{Keywords}

Parent Materials, pH, Exchangeable Acidity and Amendments

\footnotetext{
${ }^{*}$ Corresponding author.
}

How to cite this paper: Onwuka, M.I., Ozurumba, U.V. and Nkwocha, O.S. (2016) Changes in Soil pH and Exchangeable Acidity of Selected Parent Materials as Influenced by Amendments in South East of Nigeria. Journal of Geoscience and Environment Protection, 4, 80-88. http://dx.doi.org/10.4236/gep.2016.45008 


\section{Introduction}

Soil $\mathrm{pH}$ known as potential of hydrogen is a characteristic that describes the relative acidity or alkalinity of the soil. $\mathrm{pH}$ is defined as the negative (-) log or base 10 value of the concentration of hydrogen ions [1] [2]. According to [3], soil pH influences several soil factors that affect plant growth; these include soil bacteria, nutrient leaching, nutrient availability, toxic elements and soil structure.

Soil pH is also called actual or active acidity [4] and it is the measurement of free hydrogen ions $\left(\mathrm{H}^{+}\right)$on the soil colloids [5]. It is the type of acidity upon which plant growth reacts and where the free $\mathrm{H}^{+}$concentration of the soil solution vary small, compared to the reserve or exchangeable acidity [6].

Exchangeable acidity is the measure of the $\mathrm{H}^{+}$and $\mathrm{Al}^{3+}$ ions retained or fixed on soil colloid after the active acidity is measured [5]. When the exchangeable acidity of the soil is high with a resultant low $\mathrm{pH}$, it affects the soil condition and many processes in the soil. In an acidic condition, aluminum fixes phosphorus causing its deficiency in plants [7], the bioavailability of iron, aluminum, or manganese can be very high and may reach toxic levels at lower $\mathrm{pH}$ [8]. Some soil borne diseases such as clubroot caused by Plasmodiophora brassicae is a major epidemic disease when soil $\mathrm{pH}$ is lower than 5.7 [9].

One of the ways to reduce the effect of acidity on soil and plant is to increase the soil $\mathrm{pH}$. Soil $\mathrm{pH}$ can be increased by the addition of liming materials to the soil. Some of these liming materials include oxides, hydroxides and carbonates of calcium and magnesium. Others are farm yard manures, ash from different sources and biochar whose research is still new in this part of the country. All these materials have been found to increase $\mathrm{pH}$, reduce soil acidity, enhance the activities of the microorganisms especially bacterial, improve the availability of phosphorus and some other essential macro and micro nutrients, increase crop productivity and yield [10]-[13].

In applying the liming materials, care should be taken not to over lime, this is because over liming result in increased soil $\mathrm{pH}$ which leads to alkaline condition. When the soil is alkaline, the soil colloid is dominated by $\mathrm{OH}^{-}$ion. One of the effects of alkaline in the soil is the reduction in nutrient, especially micronutrient availability and a good example is iron and the condition may lead to its deficiency [14].

Having established the fact that soil acidity can be reduced by the application of the liming materials, it is paramount that the right liming material be used. This material will be such that will reduce the soil acidity, as well as increase the soil $\mathrm{pH}$, to the level that most soil properties and plant parameters will be affected positively. It is against this backdrop that the objective of this study was set. The objective therefore was to determine the effect of ash, biochar and calcium carbonate and their separate combinations with poultry manure on soil $\mathrm{pH}$ and exchangeable acidity of Sandstone, Shale and Alluvium of Abia State, Southeast of Nigeria.

\section{Materials and Methods}

The investigation was an incubation study conducted at the Laboratory of Soil Science and Meteorology Department, Michael Okpara University of Agriculture Umudike $\left(05^{\circ} 29^{\prime} \mathrm{N}, 07^{\circ} 33^{\prime} \mathrm{E}\right.$ and $122 \mathrm{~m}$ above sea level) for eighty-four days. Soils of the parent materials used for the study were collected from the farms of some smallholder rural farmers located in Abia State. The parent materials used were Shale from Bende $\left(5^{\circ} 34^{\prime} 0^{\prime \prime} \mathrm{N}, 7^{\circ} 7^{\prime} 60^{\prime \prime} \mathrm{E}\right)$, Sand stone from Abiriba $\left(5^{\circ} 42^{\prime} 0^{\prime \prime} \mathrm{N}, 7^{\circ} 43^{\prime} 60^{\prime \prime E}\right)$ and Fresh water alluvium from Owerrinta village $\left(5^{\circ} 15^{\prime} 4^{\prime \prime} \mathrm{N}\right.$, $\left.7^{\circ} 18^{\prime} 56 " \mathrm{E}\right)$. Soils were collected from each of these villages at a sampling area of $50 \mathrm{~m} \times 50 \mathrm{~m}$ and 15 soil samples randomly taken from each sampling farm.

\subsection{Soil Sampling and Preparation}

Soil samples were collected randomly from the depth of $0-15 \mathrm{~cm}$. The soil samples were bulked, air-dried, ground, and pass through a $2 \mathrm{~mm}$ sieve mesh. From the composite soil, $100 \mathrm{~g}$ of the soil was taken for each treatment into $500 \mathrm{~mL}$ beaker and labelled appropriately. The soil samples were kept on the laboratory benches. Its moisture was maintained at field capacity and the temperature was at room temperature. The samples were covered with cheese cloth to prevent evaporation. The chemical characteristics of the soil used for the study are shown on Table 1.

\subsection{Treatments and Preparation}

The treatments comprised of Control (no amendment), Biochar, Ash, Lime, Biochar + Poultry Manure, Ash + 
Table 1. Some selected physicochemical properties of the parent materials.

\begin{tabular}{cccc}
\hline & & \multicolumn{2}{c}{ Values } \\
Properties & Sandstone & Shale & Alluvium \\
\cline { 2 - 4 } & 4.96 & 4.82 & 5.31 \\
EH $\left(\mathrm{H}_{2} \mathrm{O}\right)$ & 2.31 & 2.42 & 2.13 \\
\hline
\end{tabular}

Poultry Manure and Lime + Poultry Manure. They were applied at 2 ton/ha with its equivalent of $1.43 \mathrm{~g}$ to the $100 \mathrm{~g}$ of the incubated soils for the containers that received sole amendment and $0.72 \mathrm{~g}$ each for the containers that received the combined amendments. The Biochar and Ash were prepared from the following feed stocks namely; rice husk, cowpea husk and spent mushroom substrate others were maize husk, sawdust and 2:1 clay type. Biochar was produced from the pyrolysis process using the pyrolysis drum at the temperature of $450^{\circ} \mathrm{C}$ and afterwards characterized according to Biochar material test categories and characteristic of the [15]. The lime was procured from the Ministry of Agriculture, Abia State whiles the poultry manure which was battery cage manure, was sourced from Michael Okpara University of Agriculture Farm Center. The chemical properties of the treatments determined (Table 2) were limited to the soil $\mathrm{pH}$ focused on this study.

\subsection{Experimental Procedure}

The study was a factorial experiment in completely randomized design (CRD) with two factors, namely, treatments and days of incubation. The treatments were replicated three times. The samples were incubated for eighty four days; it started from Monday $10^{\text {th }}$ March and ended on $2^{\text {nd }}$ June 2014. The soil properties determined at fourteen days intervals.

\subsection{Soil Properties Determination}

The following soil properties were determined; soil $\mathrm{pH}$ was determined with the $\mathrm{pH}$ meter in water at a ratio of 1:2.5 soils to distilled water suspension [16]; exchangeable acidity was determined by the method of Mclean (1982) as outlined by [17] using $1 \mathrm{M} \mathrm{KCI}$ as the extracting solution and titrating with $0.01 \mathrm{M} \mathrm{NaOH}$, using phenolphthalein as the indicator.

\subsection{Statistical Analysis}

The data generated were subjected to analysis of variance (ANOVA) for factorial experiment in Completely Randomized Design (CRD) using the GENSTAT package. The means were separated using the Fisher's Least Significant difference (LSD).

\section{Results}

The effect of the treatments on the soil $\mathrm{pH}$ of Alluvium is shown on Figure 1. The applied Lime + Pm significantly $(p<0.05)$ increased the soil $\mathrm{pH}$ on the $14^{\text {th }}$ and $42^{\text {nd }}$ days of incubation. While Lime $+\mathrm{Pm}$ and Lime significantly $(p<0.05)$ showed increase on $28^{\text {th }}, 56^{\text {th }}, 70^{\text {th }}$ and $84^{\text {th }}$ days of the incubation.

In Sandstone (Figure 2), the application of lime alone significantly $(p<0.05)$ increased the soil $\mathrm{pH}$ at the $14^{\text {th }}$, $28^{\text {th }}, 56^{\text {th }}$ and $70^{\text {th }}$ day of the incubation while Lime + Pm significantly $(p<0.05)$ increase the $\mathrm{pH}$ on the $42^{\text {nd }}$ and $84^{\text {th }}$ of the incubation. They two treatments were statistically at bar with each other.

The applied Lime + Pm significantly $(p<0.05)$ increased the soil pH in Shale (Figure 3$)$ at the $14^{\text {th }}, 28^{\text {th }}$ and $42^{\text {nd }}$ day of incubation with the values of 7.4, 8.4 and 8.1 respectively, though these values of Lime + Pm were statistically at par with the values of Lime for those days of incubation. On the $56^{\text {th }}, 70^{\text {th }}$ and $84^{\text {th }}$ day of incubation, both Lime $+\mathrm{Pm}$ and Lime significantly $(p<0.05)$ increased the $\mathrm{pH}$.

The result displayed on Figure 4 shows the means of the treatments on the $\mathrm{pH}$ of the parent materials. The applied treatments gave higher $\mathrm{pH}$ values on Alluvium followed by Shale and finally by Sandstone. Lime $+\mathrm{Pm}$ and sole Lime had the highest significant $(p<0.05)$ values of $\mathrm{pH}$. The values for the Lime + Pm were 8.5, 7.9 and 6.7 for Alluvium, Shale and Sandstone respectively while that of lime were 8.1, 7.8 and 6.7 for Alluvium, Shale and Sandstone in that order. 


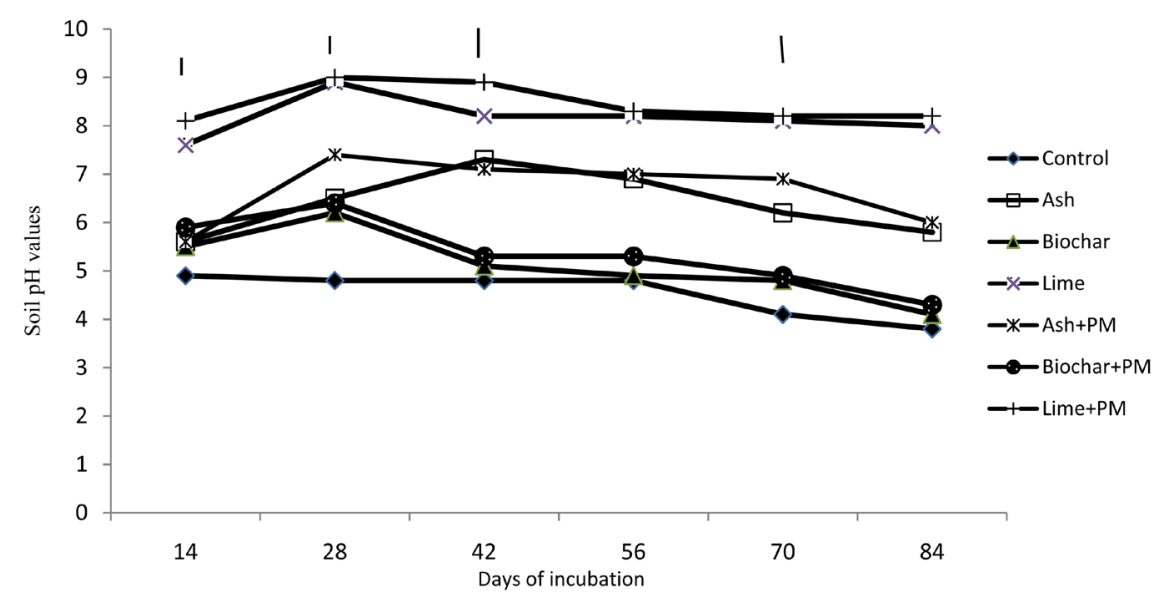

Figure 1. Treatments effect on soil pH modification in Alluvium at days of incubation. Vertical bars represent LSD at 0.05.

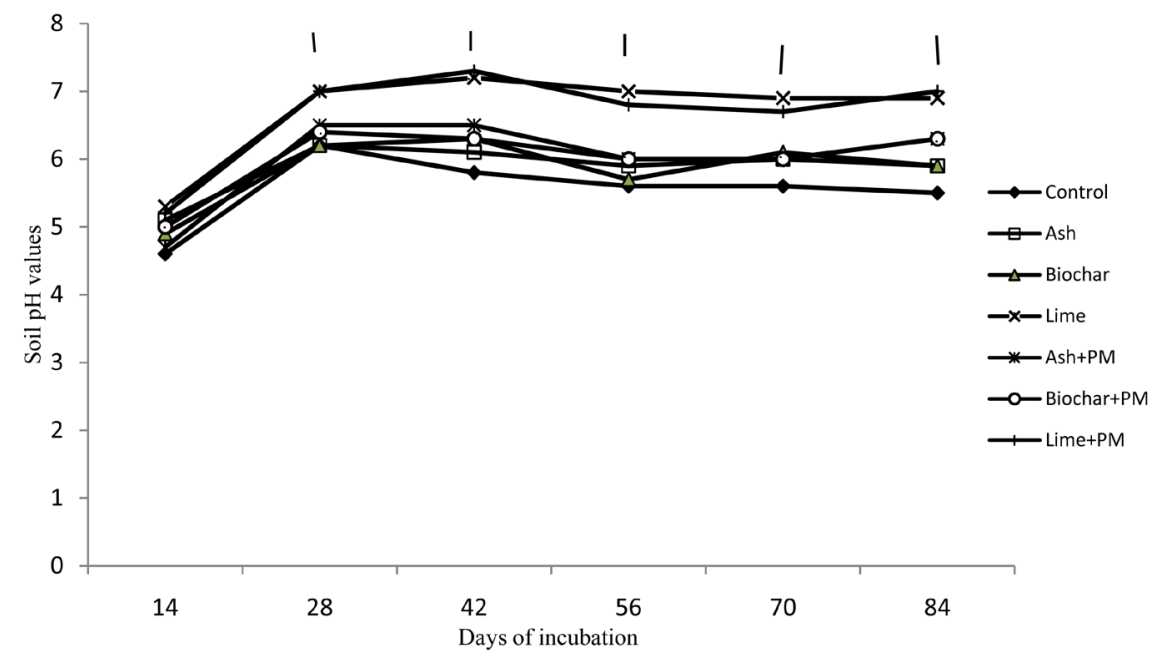

Figure 2. Treatments effect on soil pH modification in Sandstone at days of incubation. Vertical bars represent LSD at 0.05 .

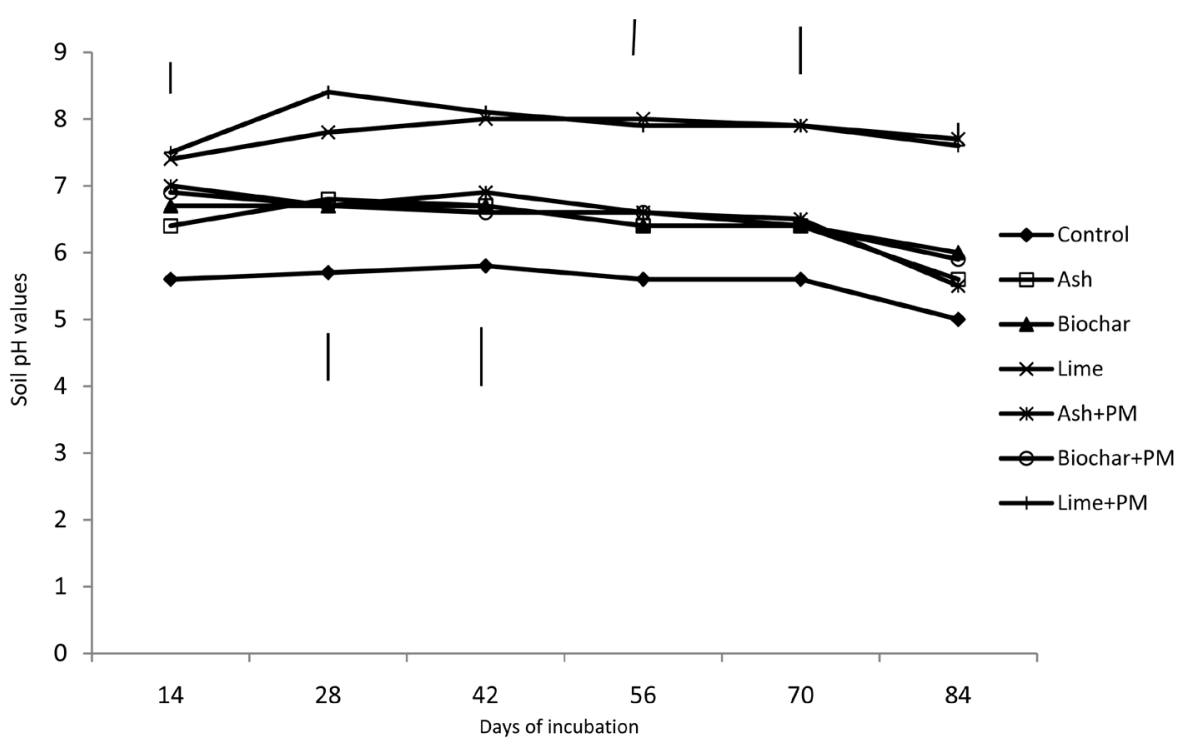

Figure 3. Treatments effect on soil pH modification in Shale at days of incubation. Vertical bars represent LSD at 0.05. 


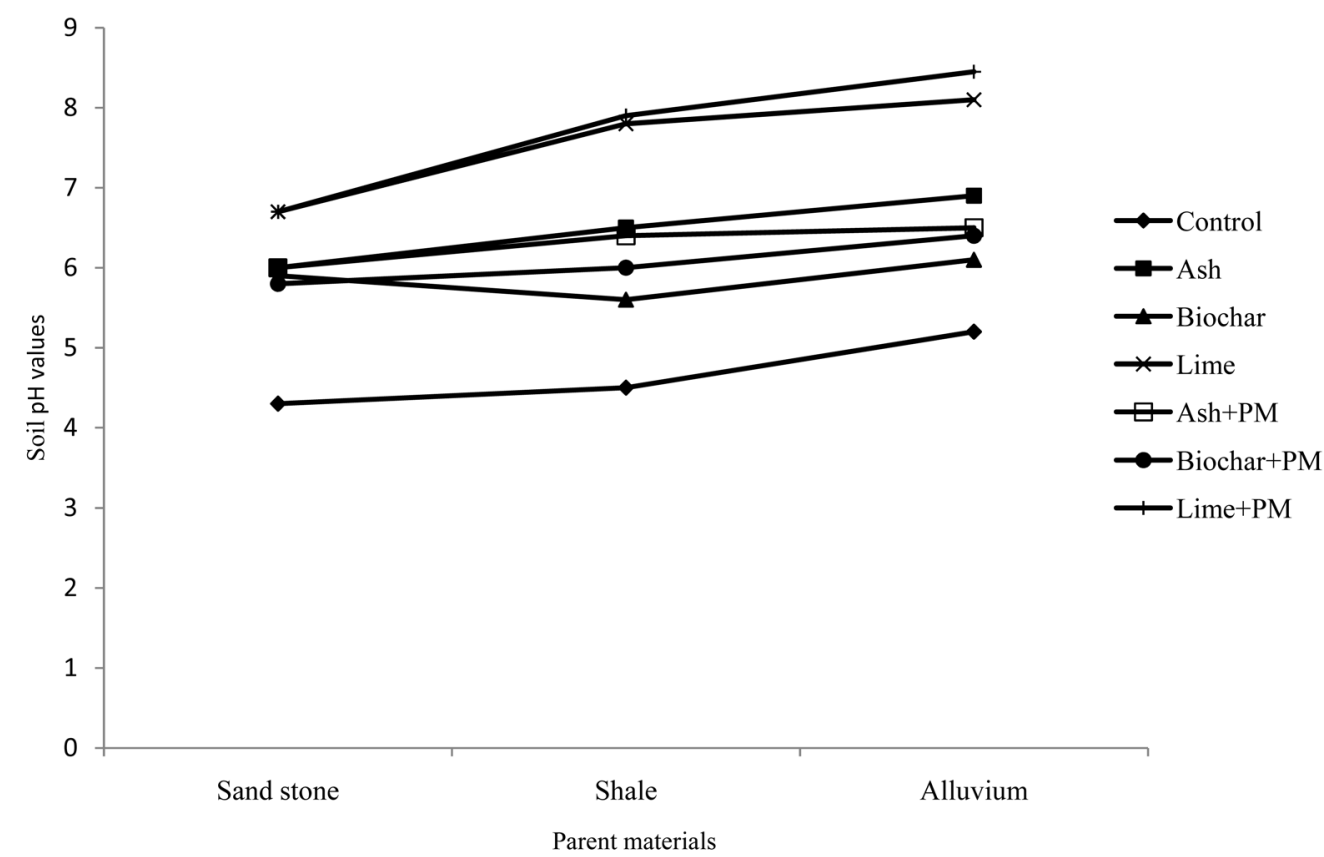

Figure 4. Effect of the means of the treatments on $\mathrm{pH}$ of the parent materials. Vertical bar represent lsd at 0.05.

Table 2. Chemical composition of the amendments used for the study.

\begin{tabular}{ccccc}
\hline Properties & Lime & Ash & Biochar & Poultry manure \\
\hline $\mathrm{pH}\left(\mathrm{H}_{2} \mathrm{O}\right)$ & 9.9 & 8.4 & 7.2 & 7.0 \\
\hline
\end{tabular}

The result of the means of the days of incubation on soil pH of the parent materials is shown on Figure 5, the result indicated that the highest significant $(p<0.05)$ values $\mathrm{pH}$ for the three parent materials were obtained on the $28^{\text {th }}$ day of the incubation. The values were as follows: 6.6 for Shale, 6.9 for Sandstone and 7.2 for Alluvium. The $\mathrm{pH}$ of parent materials after the $28^{\text {th }}$ day started decreasing to the $84^{\text {th }}$ day of the incubation.

The effect of the treatments on soil exchangeable acidity on Shale is shown on Figure 6. The result obtained showed that at the days of the incubation, Lime and Lime + Pm significantly $(p<0.05)$ decreased the soil exchangeable acidity except for the $84^{\text {th }}$ day of the incubation whereas the pots that received Lime had an increased exchangeable value when compared to that of the Lime $+\mathrm{Pm}$.

The application of Lime and Lime + Pm significantly $(p<0.05)$ decreased the values of soil exchangeable acidity in Sandstone (Figure 7) over the other treatments investigated.

The result on Figure 8, which showed the effect of the treatment on the exchangeable acidity of Alluvium, indicated that all the applied amendments reduced the exchangeable acidity over the control. However, on the $14^{\text {th }}, 42^{\text {nd }}, 56^{\text {th }}, 70^{\text {th }}$ and $84^{\text {th }}$ days of the incubation, Lime + Pm significantly $(p<0.05)$ decreased the exchangeable acidity compared to the other treatments. On the $28^{\text {th }}$ of the incubation, Lime significantly $(p<0.05)$ reduced the soil acidity.

Considering the means of treatments effect on the acidity of the parent materials presented on Figure 9. It was observed that Lime and Lime $+\mathrm{Pm}$ had the lowest values of exchangeable acidity in the three parent materials investigated. Whereas Alluvium had the lowest exchangeable acidity values, Sandstone had the highest values for the exchangeable acidity.

The applied treatments had the lowest significant $(p<0.05)$ values of exchangeable acidity on the $28^{\text {th }}$ of the incubation (Figure 10). There was a sharp rise from the $42^{\text {nd }}$ to the $84^{\text {th }}$ day of the incubation in Sandstone. In shale, there was a gradually increase of the acidity from $42^{\text {nd }}$ to $84^{\text {th }}$ day while in Alluvium, the gradual increased attained its highest value on the $84^{\text {th }}$ day of the incubation. Alluvium had the lowest values for the exchangeable acidity with the values of $1.14,1.09,1.13,1.19$ and $1.3 \mathrm{cmol} \cdot \mathrm{kg}^{-1}$ at the $14^{\text {th }}, 28^{\text {th }}, 42^{\text {nd }}, 56^{\text {th }}$ and $70^{\text {th }}$ day of the incubation when compared to the other parent materials. 


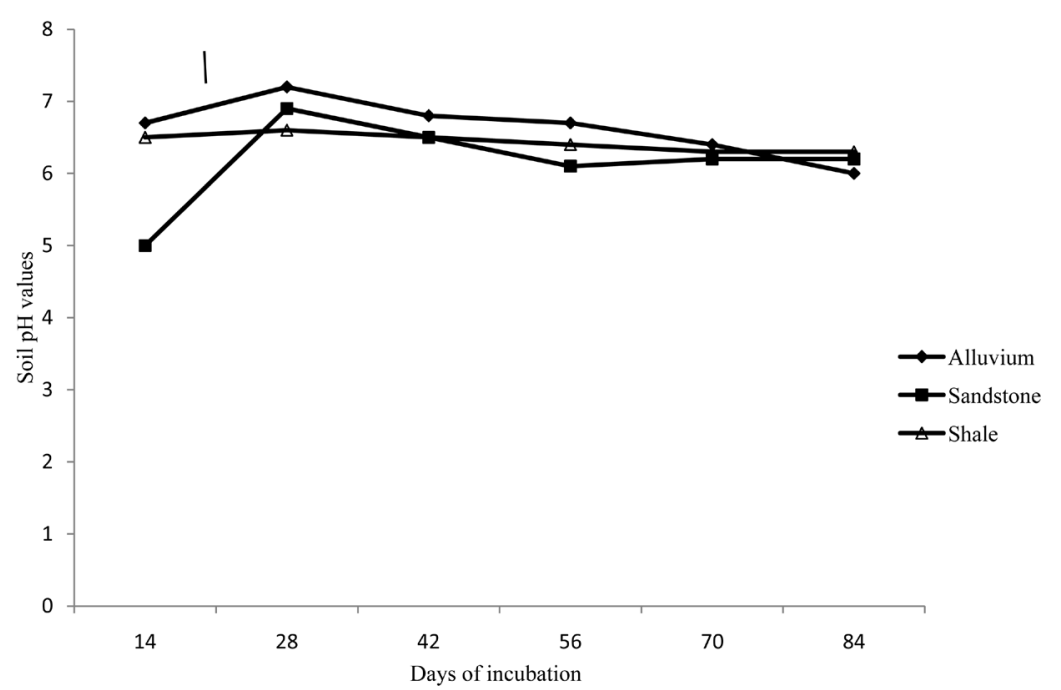

Figure 5. Means of days of incubation on soil pH of the parent materials. Vertical bar represents LSD at 0.05 .

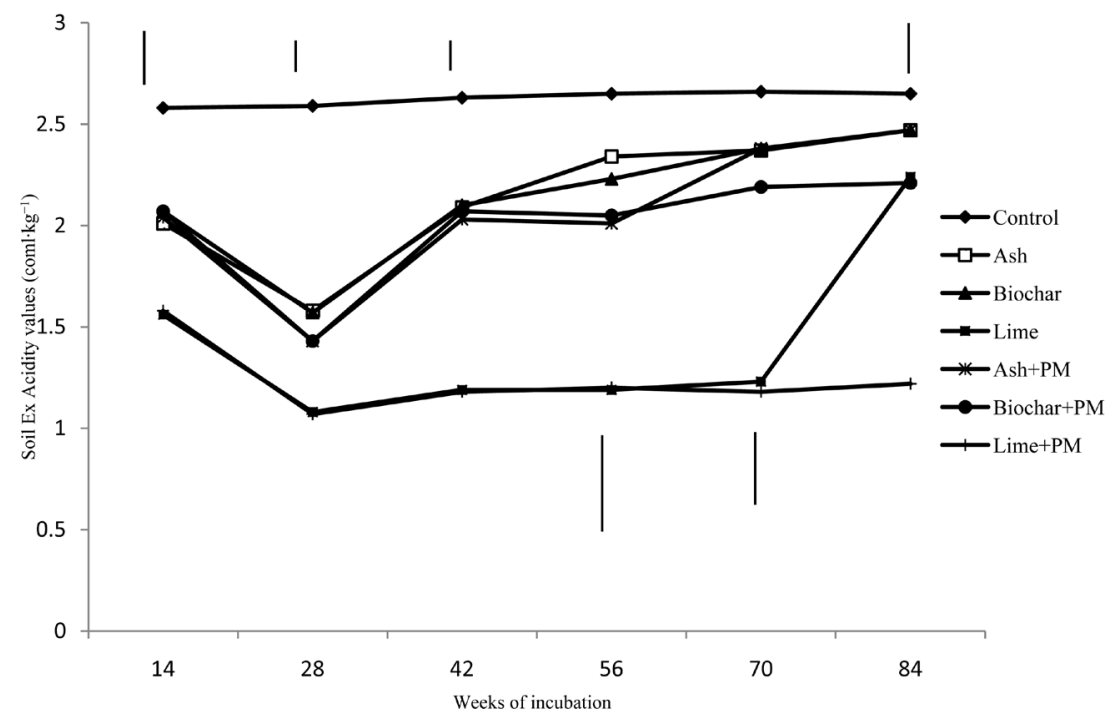

Figure 6. Treatments effect on soil exchangeable acidity $\left(\mathrm{cmol} \cdot \mathrm{kg}^{-1}\right)$ modification in Shale at days of incubation. Vertical bars represent LSD at 0.05 .

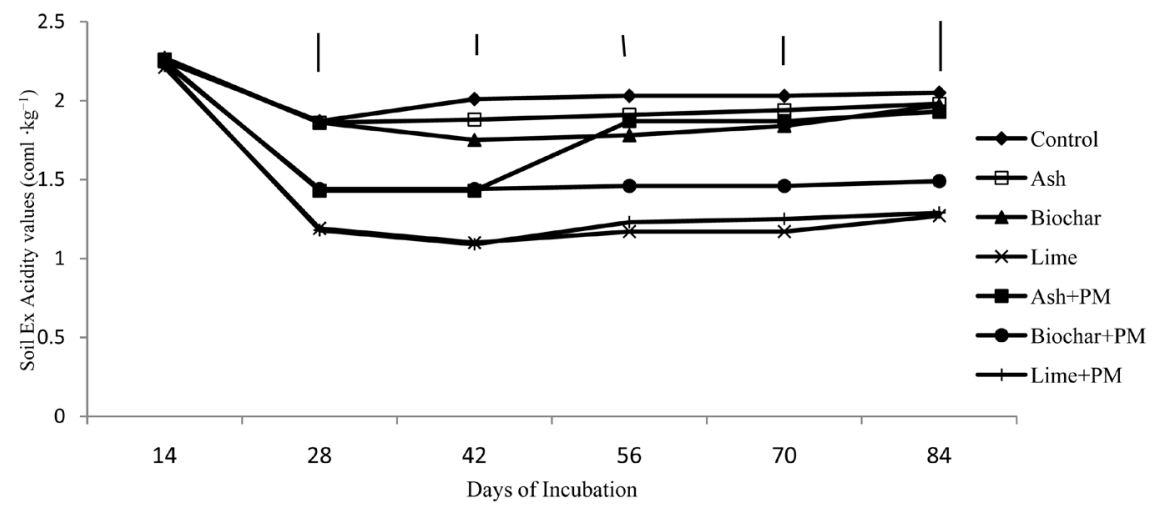

Figure 7. Treatments effects on soil exchangeable acidity $\left(\mathrm{cmol} \cdot \mathrm{kg}^{-1}\right)$ modification in Sandstone at days of incubation. Vertical bars represent Lsd at 0.05 . 


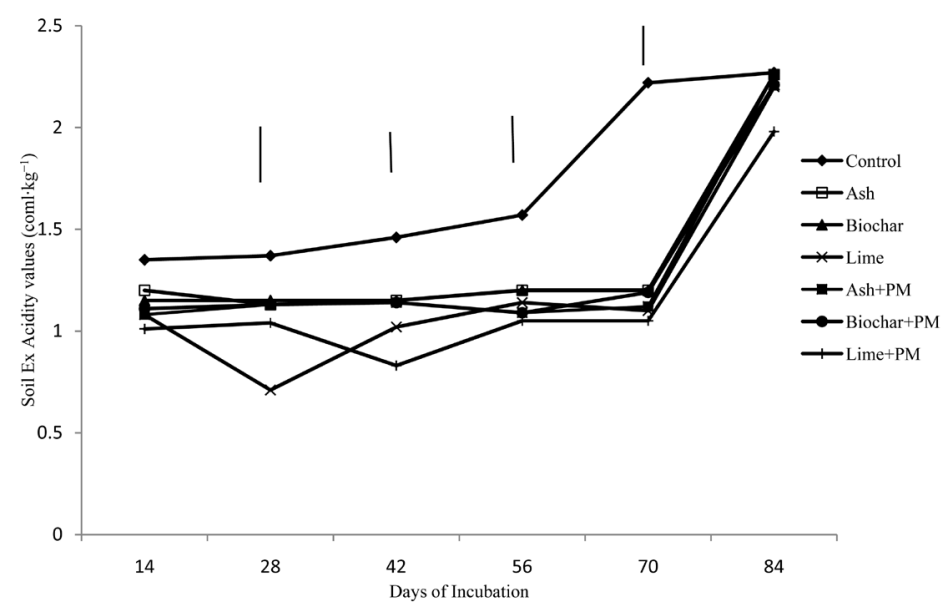

Figure 8. Treatments effect on soil exchangeable acidity $\left(\mathrm{cmol} \cdot \mathrm{kg}^{-1}\right)$ modification in Alluvium at days of incubation. Vertical bars represent LSD at 0.05 .

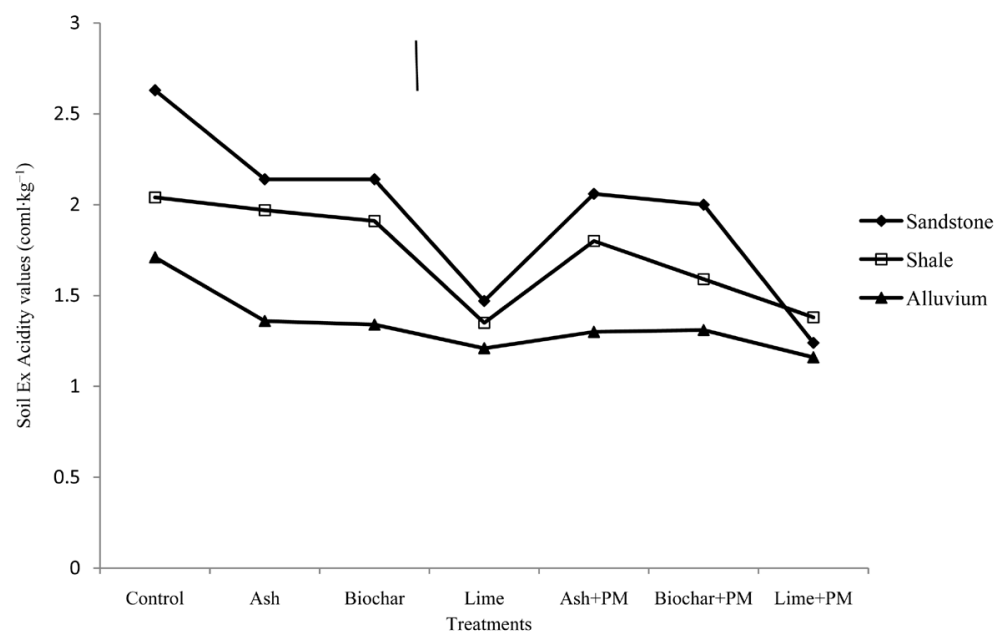

Figure 9. Means of treatments on soil exchangeable acidity $\left(\mathrm{cmol} \cdot \mathrm{kg}^{-1}\right)$ of the parent materials. Vertical bar represent lsd at 0.05 .

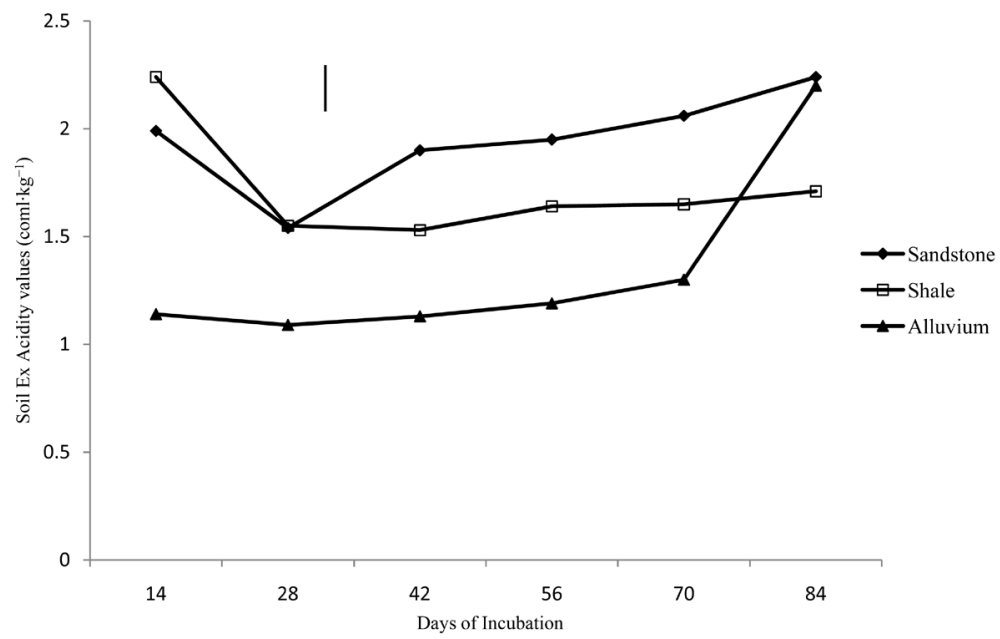

Figure 10. Means of days of incubation on soil exchangeable acidity $\left(\mathrm{cmol} \cdot \mathrm{kg}^{-1}\right)$ of the parent materials. Vertical bar represent lsd at 0.05 . 


\section{Discussions}

Soil $\mathrm{pH}$ is the measurement of the concentration of hydrogen ion in soil solution. When the concentration of hydrogen ions in the soil water solution is high, the $\mathrm{pH}$ is lowered and the lower the $\mathrm{pH}$ value, the higher the acidity of the soil. The pre-treatment analysis of the soil on Table 1 shows that the soils from the three parent materials had $\mathrm{pH}$ ranges of 4.82 - 5.31. Soils with these $\mathrm{pH}$ ranges and below are said to be strongly acidic [18]. The acidity of the soil affects most reactions in the soil such as aluminum, iron, manganese and zinc solubility and their toxicities to crops [19]. The application of the amendments improved the soil $\mathrm{pH}$ from the pre-treatment values of 4.82 - 5.31 to post-treatment values of 5.6 - 8.5 (Figure 4). This shows that the amendments have the ability to reduce the $\mathrm{H}^{+}$ions in the soil solution [20]. The amendments were able to bring an increase in soil pH and decrease in exchangeable acidity by neutralizing the acidity. When the exchangeable acidity is neutralized, the $\mathrm{Al}^{3+}$ ion is displaced from the exchange site into the soil solution, where it is hydrolyzes, splitting water and releasing a hydrogen ion to the solution. Another way by which the exchangeable acidity is reduced is by the addition of organic materials. When organic materials are added in the form of manure, ash and biochar they form strong bonds known as chelates with aluminum and this gives rise to the reduction of the solubility of aluminum and soil acidity.

The ability of a liming material added to the soil to neutralize acidity will depend on the parent material and the Acid Neutralizing Capacity (ANC) of the soil [21]. This may explain why Sandstone had lower $\mathrm{pH}$ values (Figure 4) and highest exchangeable acidity (Figure 9) compared to the other parent materials even after the application of the amendments. According to [21] Sandstone has less ANC, a lower pH and its acidity is not completely neutralized, because of the influence of the parent material through its basic cation content.

The highest $\mathrm{pH}$ and lowest exchangeable acidity values recorded in pots that received Lime and Lime $+\mathrm{Pm}$ in the three parent materials (Figure 4 and Figure 9), were in conformity with the findings of [22] [23]. They found in their works that the application of lime and manure increased the soil $\mathrm{pH}$ and reduced the exchangeable acidity. [22] attributed the increase in $\mathrm{pH}$, to the mineralization of the manure which released $\mathrm{Ca}^{+2}$ ions that went into solution, hydrolyzed and react with soluble $\mathrm{Al}^{+3}$ ions to form insoluble $\mathrm{Al}(\mathrm{OH})_{3}$ and water. [23] attributed the increase by lime to the high amount of calcium which it contained.

The $\mathrm{pH}$ range of 6.7 - 8.5 obtained by the application of lime and lime +Pm (Figure 4) was high. It has been reported by some researchers that this $\mathrm{pH}$ range affect lots of processes in the soil. For instances as soil $\mathrm{pH}$ approaches 6.5, iron and manganese begin to change into insoluble forms that are unavailable for root uptake and plants utilization. As $\mathrm{pH}$ increases above 6.5, iron and manganese unavailability intensifies [24] hence their deficiencies occur. At high $\mathrm{pH}$ values also calcium form calcium phosphate with phosphorus making it unavailable and this ultimately leads to phosphorus deficiency [25].

Going by the points stated above about the $\mathrm{pH}$ range of 6.7 - 8.5, it may not be appropriate to apply lime and lime $+\mathrm{Pm}$ to the soil, based on this research result. Rather the application of Biochar and biochar + PM may be more suitable. This is because their $\mathrm{pH}$ range which is $5.6-6.4$ are the most nearest to the $\mathrm{pH}$ range of $5.5-7.0$ which have been reported by researchers to be the optimum $\mathrm{pH}$ for most soil activities. These activities include effective bacterial functioning, bioavailability of most plantmicro and macronutrients for plant use, availability of phosphorus, formation of clay into granules among others [3] [8] [24].

\section{Conclusion}

The results from the incubation work explicitly showed that the application of soil amendments namely: Ash, Lime, Biochar and their combinations with poultry manure on three parent materials namely: Sandstone, Shale and Alluvium, increased the soil $\mathrm{pH}$ and decreased the soil exchangeable acidity over the control. Lime and Lime $+\mathrm{Pm}$ gave the highest $\mathrm{pH}$ values and the lowest exchangeable acidity values among the amendments tested in all the parent materials. The values given by Lime and Lime + Pm were from neutral to moderately alkaline; this has been reported to be unconducive for most soil activities. Biochar and Biochar + Pm which shows $\mathrm{pH}$ from moderately acidic to near neutral, may be the best amendment to work with since the $\mathrm{pH}$ range is within the optimum $\mathrm{pH}$ value for most soil activities. We are therefore proposing that Biochar and Biochar $+\mathrm{Pm}$ could be better used to increase the soil $\mathrm{pH}$ and reduced the acidity in the three parent materials studied. Further field work is recommended to verify this result.

\section{References}

[1] McCauley, A., Jones, C. and Jacobsen, J. (2009) Nutrient Management. Module No. 8, Montana State University Ex- 
tension Publications. http://www.msuextension.org

[2] Benton, J.J. (2012) Plant Nutrition and Fertility Manual. 2nd Edition, CRC Press, Taylor and Francis Group, Florida, 27.

[3] Perry, L. (2015) pH for the Garden. www.pss.uvm.edu/ppp/pubs/oh34.htm

[4] Sanaullah, A.F.M. and Shamsuddin, A.M. (2010) Distribution of Active Acidity, Reserve Acidity, Clay Content and Cation Exchange Capacity of Some Soils of Sathgaon Tea Estate, Bangladesh. Journal of Applied Sciences Research, 6 , 1627.

[5] McCarty, L.B., Rodriguez, I.R., Bunnell, B.T. and Waltz, F.O. (2003) Fundamentals of Turf Grass and Agricultural Chemistry. John Wiley and Sons Inc., Hoboken, New Jersey, 1198.

[6] Tan, K.H. (1998) Principles of Soil Chemistry. CRC Press Amazon, 369.

[7] Thomson, C.J., Marschner, H. and Römheld, V. (1993) Effect of Nitrogen Fertilizer Form on pH of the Bulk Soil and Rhizosphere, and on the Growth, Phosphorus, and Micronutrient Uptake of Bean. Journal of Plant Nutrition, 16, 493506. http://dx.doi.org/10.1080/01904169309364548

[8] Liu, G., Mylavarapu, R., Hanlon, E. and Lee, C.W. (2014) Soil pH Management for Optimum Commercial Fruit Production in Florida. http://edis.ifas.ufl.edu

[9] Sylvia, D.M., Fuhrmann, J.F., Hartel, P.G. and Zuberer, D.A. (2005) Principles and Applications of Soil Microbiology. Pearson Education, Upper Saddle River.

[10] Ano, A.O. and Agwu, J.A. (2005) Effect of Animal Manures on Selected Soil Chemical Properties, Organic Matter, pH, Exchangeable Ca, and Mg. Nigeria Journal of Soil Science, 15, 14-19.

[11] Uzoho, B.U. and Oti, N.N. (2005) Phosphorus Adsorption Characteristics of Selected Southeastern Nigerian Soils. Agro-Science Journal of Agriculture, Food, Environment and Extension, 4, 50-55.

[12] Lee, C.H., Lee, H., Lee, Y.B., Chang, H.H., Ali, M.A., Min, W., Kim, S. and Kim, P.J. (2007) Increase of Available Phosphorus by Fly-Ash Application in Paddy Soil. Communications in Soil Science and Plant Analysis, 38, 1551-1562.

[13] Onwuka, M.I. and Ihejiakor, C.N. (2013) Residual Effect of Integrated Nutrient Management Approach on the Growth and Yield of Amaranthus (Amaranthus cruentus L.) on an Acidic Soil of Southeastern Nigeria. Greener Journal of Agricultural Sciences, 3, 778-786.

[14] Cox, L and Koenig, R. (2010) Solutions to Soil Problems ii. High pH (Alkaline Soil). http://extension.usu.edu

[15] IBI Biochar Standards Version 2.0 (2014) Standardized Product Definition and Product Testing Guidelines for Biochar That Is Used in Soil. The International Biochar Initiative http://www.biochar-international.org/characterizationstandard

[16] Thomas, G.W. (1996) Soil pH and Soil Acidity. In: Bingham, J.M., et al., Eds., Methods of Soil Analysis Part 3. Chemical Methods, Soil Science Society of America, and America Society of Agronomy, Madison, Wisconsin, 5: 475-490.

[17] Udo, E.J., Ibia, T.O., Ogunwale, J.A., Ano, A.A. and Esu, I.E. (2009) Manual of Soil, Plant and Water Analyses. Sibon Books Limited, Lagos, 31-33.

[18] Chude, V.O., Olayiwola, S.O., Daudu, C. and Ekeoma, A. (2012) Fertilizer Use and Management Practice for Crops in Nigeria. 4th Edition, Produced by Federal Fertilizer Department, Federal Ministry of Agriculture and Rural Development, Abuja, 40.

[19] Osakia, M., Watanabe, T. and Tadano, T. (1997) Beneficial Effect of Aluminum on Growth of Plants Adapted to Low pH Soils. Soil Science and Plant Nutrition, 43, 551-563. http://dx.doi.org/10.1080/00380768.1997.10414782

[20] Wortmann, C.S. and Shapiro, C.A. (2009) Management Strategies to Reduce the Rate of Soil Acidification. University of Nebraska-Lincoln Extension, Lincoln, NE. http://www.ianrpubs.unl.edu

[21] Funakawa, S., Watanabe, T., Nakao, A., Fuji, K. and Kosaki, T. (2012) Pedogenetic Acidification in Upland Soils under Different Bioclimatic Condition in the Humid Asia. In: Lal, R. and Stewart, B.A., Eds., World Soil Resource and Food Security, Taylor and Francis Group LLC, Florida, 243.

[22] Ano, A.O. and Ubochi, C.I. (2007) Neutralization of Soil Acidity by Animal Manures: Mechanism of Reaction. African Journal of Biotechnology, 6, 364-368.

[23] Onwuka, M.I. (2011) The Chemical Composition of Different Sources of Liming Materials and Their Effect on Soil Chemical Properties. Journal of Environmental Sciences and Resource Management, 3, 57-67.

[24] Zuzek, K. and Zlesak, D. (2015) Iron and Manganese Deficiencies in Woody Plants. http://www.extension.umn.edu

[25] Duncan, M.R. (2002) Soil Acidity and P Deficiency: Management Strategies for the Northern Tablelands of NSW, NSW Agriculture, Leaflet No. 9 of Acid Soil Management Series. http://www.dpi.nsw.gov.au 